\title{
Vegetation and ecosystem carbon recovery following shifting cultivation in Mizoram- Manipur-Kachin rainforest eco-region, Southern Asia
}

\author{
Anudip Gogoi ${ }^{1}$ (D) Uttam Kumar Sahoo ${ }^{1 *}$ (D) and Hemanta Saikia ${ }^{2}$ (D)
}

\begin{abstract}
Background: Shifting cultivation (locally known as "jhum") is a major driver of deforestation and loss of ecosystem services in rainforests. For developing any effective conservation of biodiversity and carbon service program, an indepth understanding to the recovery of vegetation and carbon after abandonment of jhum is essential. We estimated species richness, abundance and composition of trees, shrubs and herbs, carbon distribution in aboveground and belowground components along a chronosequence of jhum fallow in northeast India, and elucidated the factors affecting the recovery processes of jhum fallows.
\end{abstract}

Methods: Species composition and other plant community attributes, carbon storage in different pools were studied in 5 jhum fallows ( $<5,5-10,11-15,16-20,21-25$ years old) and an old-growth forest. The data were subjected to linear mixed effect modeling using R-package "nIme" for identifying the important factors contributing to the recovery of vegetation and carbon.

Results: Species composition varied significantly $(P<0.05)$ between jhum fallows and old-growth forest. Tree density varied from 28 stems ha ${ }^{-1}$ in 5 years old jhum fallow to 163 stems ha $^{-1}$ in old-growth forest. Both biomass carbon in all components and soil organic carbon were significantly $(P=0.01)$ lower in jhum fallows than in the old-growth forest except living non-woody biomass component. The recovery of aboveground biomass carbon was faster during early successive years than the mid-successive jhum fallows. Total ecosystem carbon and soil organic carbon stock in the oldest jhum fallow was 33\% and 62\% of those in the old-growth forest, respectively. The fallow age was found to be the most important explanatory factor in the recovery process of vegetation and carbon stock in re-growing fallows.

Conclusion: The shifting cultivation fallows gradually recovered both vegetation and carbon and are potential repository sites for biodiversity conservation, which may take much longer time to reach up to old-growth forest in northeast India.

Keywords: Biodiversity conservation, Regrowth forest, Vegetation succession, Carbon storage, Restoration of degraded land

\footnotetext{
*Correspondence: uksahoo_2003@rediffmail.com

'Department of Forestry, Mizoram University, Aizawl 796004, India

Full list of author information is available at the end of the article
}

\section{Springer Open}

(c) The Author(s). 2020 Open Access This article is licensed under a Creative Commons Attribution 4.0 International License, which permits use, sharing, adaptation, distribution and reproduction in any medium or format, as long as you give appropriate credit to the original author(s) and the source, provide a link to the Creative Commons licence, and indicate if changes were made. The images or other third party material in this article are included in the article's Creative Commons licence, unless indicated otherwise in a credit line to the material. If material is not included in the article's Creative Commons licence and your intended use is not permitted by statutory regulation or exceeds the permitted use, you will need to obtain permission directly from the copyright holder. To view a copy of this licence, visit http://creativecommons.org/licenses/by/4.0/. 


\section{Introduction}

Shifting cultivation (also known as slash-and-burn agriculture) has been the subject of much debate over the past decades. While some ecologists believe that this form of agriculture being primitive results in severe environmental problem, loss of forest cover and biodiversity, erosion of top soil, desertification and decline in forest productivity (Myers 1991; Bandy et al. 1993), others support this agriculture as it is intricately linked with the socio-cultural and economic wellbeing of the indigenous people in the tropics and provide subsistence livelihood to millions of people worldwide (Brady 1996). Some ethnologists favour this system as a diversified, organic system well adapted to local environment and hill tracts. The economic and energy efficiency of shifting cultivation in northeast India (Ramakrishnan 1992) shows it to be higher than alternate form of agriculture such as terrace cultivation and valley cultivation. The economic security provided by shifting cultivation and its cultural importance provided to indigenous tribes over other sedentary agriculture partly explains its persistence over the years despite the fact it is blamed as the major cause of forest loss, turning it into targets of policy interventions (Griffiths 2008; Fox et al. 2014; Erni 2009). Though such policies and policy-oriented research program have pushed a transformation of lives and livelihoods of many people, such economic oriented objectives are also critical drivers of deforestation (Ickowitz 2006).

Shifting cultivation (locally known as "jhum") practiced in rainforests in northeast India typically involves small clearing followed by burning to release nutrient to the soil. The potential for secondary regrowth to rescue tropical forest following suspension of jhum may depend on several factors such as seed bank disturbance, presence of resproutes, and seed dispersal from surrounding forests (Kammesheidt 1999; Ulh 1987, Vieira and Proctor 2007). The age of the fallow, past history on jhum cycles, patch size, slope, and other edaphic conditions (Mukul et al. 2016) also influence the biomass and vegetation recovery. The importance of secondary forests in contributing various ecosystem services has been highlighted by many other researchers (Badalamenti et al. 2019; Yang et al. 2019). The pattern of changes and contribution level of carbon stock in various components of ecosystem in Guatemala (Fearnside and Guimaraes 1996), Cameroon (Kotto-Same et al. 1997), China (Yang et al. 2019), and Mediterranean island ecosystems (Badalamenti et al. 2019) during succession reveal the potential role of these secondary forests in maintaining carbon storage function similar to that of primary forests. Several efforts have been made to document the recovery of biodiversity in secondary forests elsewhere (Fergusan et al. 2001; Klanderud et al. 2010;
Liu et al. 2017; Longworth and Williamson 2018; Liu et al. 2019; Rozendaal et al. 2019; Yirdaw et al. 2019).

In northeast India, the dynamics of crop-fallow rotation cycles in shifting cultivation fallows, however, are poorly understood (Thong et al. 2018). The most preferred jhum fallows in the region remains 7-11 years (Thong et al. 2019) against most believed that jhum cycle has drastically reduced but the study shows that increase in the population has nevertheless decreased the patch size of the jhum field (Thong et al. 2019). Secondary forests in the state of Mizoram cover $63 \%$ of the total $21,087 \mathrm{~km}^{2}$ forest covers. These forests are predominantly occupied by bamboo forests interspersed with other tree species and present a major carbon sink that rapidly accumulates aboveground biomass. Little is known about the carbon stock of these forests with different stages of secondary succession. The potential for carbon mitigation through vegetation and biomass recovery in the re-growing tropical forests will be very desirable for developing forest conservation strategies. Besides, this information may contribute to the Intended Nationally Determined Contributions (iNDCs) to emission reductions in the UN Framework Convention on Climate Change (UNFCCC). The carbon stock recovery following slash-and-burn agriculture may be related to regeneration strategies and biomass accumulation of species with succession stages. The transition in shifting cultivation may manifest in alternation of vegetation cover and livelihood system, leading to a diversity of implications on related carbon stock and climate change pressure (Borah et al. 2018). It is therefore important to understand how the species richness and abundance of different plant communities develop after abandonment, how different environmental variables affect the recovery of plant species richness and dominance, and finally, how different fallows contribute to the carbon stock and help mitigate climate change. Besides, what are the contributions of different carbon pools to the total carbon storage in secondary forests of different ages and how do the communities, especially the woody communities relate to carbon storage. We hypothesize that vegetation recovery in terms of species richness irrespective of communities will increase with increase age of fallows, following slash-and-burn cultivation; however, the species dominance will vary with succession. The carbon recovery may also be quite conspicuous with increased age of jhum fallows thereby depicting their role as carbon sink.

\section{Materials and methods}

\section{Ethical statement}

Field samples were collected from different jhum fallows and old-growth forest stands after obtaining prior permission from the farmers and Forest Department, 
Government of Mizoram, India. Since we adopted nondestructive sampling methods, we confirm that the field sampling did not involve any kind of destruction to the plants and animal species under protection in the study area.

\section{Study area}

The study sites are located in Dampa Tiger Reserve of Mizoram in northeast India (Fig. 1). This reserve forest is the second largest protected area under the MizoramManipur-Kachin Rainforests Eco-region after Htamanthi Wildlife Century of North-Western Burma. Biological distinctiveness of this eco-region has been characterized as globally outstanding (WWF). The rugged mountains of this eco-region divide the Brahmaputra and Irrawaddy valleys and represent the semi-evergreen sub-montane rainforests that extend from the mid-ranges of the ArakanYoma and Chin Hills, North into Chittagong Hill tracts of Bangladesh, the Mizo and Naga Hills of the Indo-Burma border into the Northern Hills of Burma (WWF). The vegetation at the lower reaches is deciduous forest while the reserve harbors ever-green and semi-evergreen forests (Champion and Seth 1968) with natural grassland at higher elevation (> $1000 \mathrm{~m}$ a.s.l.). The dominant tree species in the primary forest area includes Mesua ferrea, Dipterocarpus turbinatus, D. retusus, Castanopsis indica, Terminalia myriocarpa, $T$. bellerica, Syzygium cumuni, Adina cordifolia, Bischofia javanica, Garcinia cowa, and Michelia spp. Dampa was notified as wildlife sanctuary in 1985 and re-notified as a Tiger Reserve Forest in 1994. The core area of the forest covers $500 \mathrm{~km}^{2}$ and the buffer area covers $488 \mathrm{~km}^{2}$ (Department of Forest, Environment and Climate Change, Mizoram, Govt. of India). Until the early 1990s, large parts of the core area were under shifting cultivation (jhum). Despite the protection measures taken by the concern authority, shifting cultivation has severely affected the reserve forest. According to the satellite imagery, a total of $43.41 \mathrm{~km}^{2}$ area of the core area have already been affected by shifting cultivation, which led to the prominent increment of the bamboo and scrub forests in the protected forest and ultimately resulted in only $95.27 \mathrm{~km}^{2}$ of close canopy forests in the study area. The forest is geographically located within $23^{\circ} 23^{\prime} 15^{\prime \prime}$

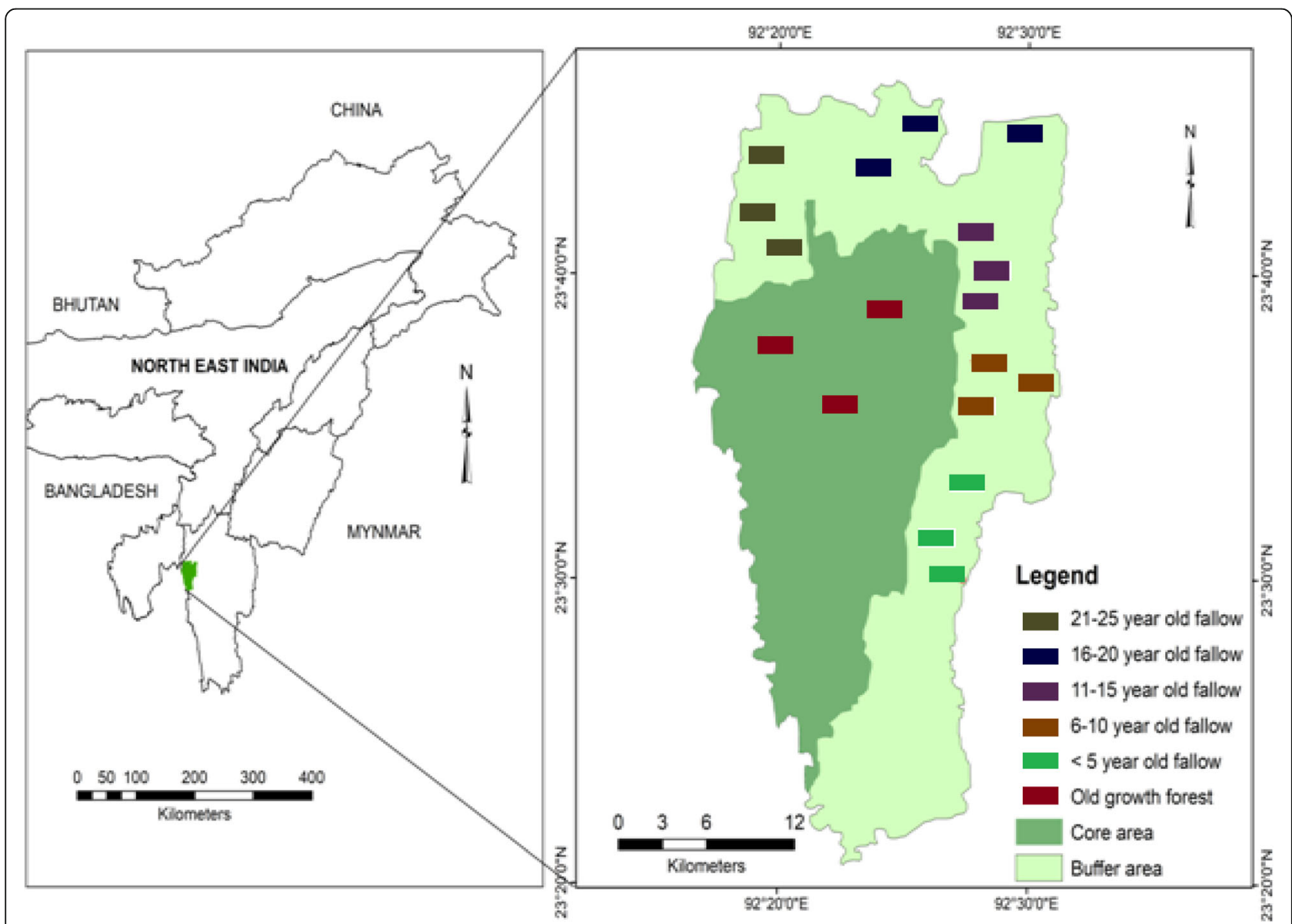

Fig. 1 Map of the study area showing locations of the old-growth forest plots in the core area and differently aged shifting cultivation fallows plots in the buffer area 
$\mathrm{N}-23^{\circ} 42^{\prime} 20^{\prime \prime} \mathrm{N}$ latitudes and $92^{\circ} 16^{\prime} 25^{\prime \prime} \mathrm{E}-92^{\circ} 25^{\prime} 55^{\prime \prime}$ $\mathrm{E}$ longitudes in the southern most corner of northeast India along a transitional zone with the Chittagong Hill Tract of Bangladesh. This forest also forms an important part of the Indo-Burma biodiversity hotspot (Myers et al. 2000). The altitude of the forest ranges from 50$1095 \mathrm{~m}$ a.s.l. with an annual rainfall of $>3000 \mathrm{~mm}$ and mean temperature ranges from 12 to $25^{\circ} \mathrm{C}$ during winter and between 22 to $35^{\circ} \mathrm{C}$ during summer.

\section{Site selection}

We selected three old-growth primary forest stands in the core area and differently aged shifting cultivation fallows in the buffer area of the protected rainforest. While selecting the primary forest stands, maximum visual attention was taken so that the impact of anthropogenic disturbances could be avoided. The farmers usually practice 5-10 year jhum cycle in the study area. More than 25-year-old fallow lands were rare in Mizoram. Therefore, we selected a chronosequence of five fallow age groups, starting from less than 5 to 25 years old fallows (i.e., < 5, 6-10, 11-15, 16-20, and 21-25 years old) for the present study. Identification of the differently aged shifting cultivation fallows was made with the help of experienced local cultivators as well as village council members who are responsible for yearly allotment of jhum lands to the farmers.

\section{Sampling}

To represent the vegetation, biomass and carbon accumulation pattern in the old-growth forest, three replicates of $250 \times 250 \mathrm{~m}$ sized plots were established in the primary forest stands of the core area. The equal numbers of plots were established in each jhum fallow age group. Due to no available larger-sized area, we reduced the plot size to $100 \times 100 \mathrm{~m}$ in shifting cultivation fallows. Thus, the whole study covers 18.75 ha sampling area in the core area and 15 ha in the buffer area of the protected rainforest.

At each corner of the plot, four $31.62 \times 31.62 \mathrm{~m}(0.1$ ha) subplots were demarcated for tree vegetation and biomass inventory. For understory vegetation and biomass enumeration, two $5 \times 5 \mathrm{~m}$ subplots were nested for shrubs within each tree subplot and four $1 \times 1 \mathrm{~m}$ quadrats (two for herbs and two for standing litter) were taken for herbs and litter components within each shrub subplot. Deadwoods and lianas were inventoried within the tree subplots. Tree saplings and the bamboo species that grew in the shifting cultivation fallows were inventoried within the shrub subplots. Tree seedlings were inventoried within the herb quadrats. Soil samples were collected at depths of $0-15,15-30$, and $30-45 \mathrm{~cm}$ from three random locations within each tree subplot. Samples from each depth class were later air-dried and mixed to get three composite samples for each study site.

All tree and liana individuals of $\geq 5 \mathrm{~cm}$ DBH occurring within the tree subplots were serially tagged and their diameter was measured at $1.37 \mathrm{~m}$ above the ground. Individuals of tree species $<5 \mathrm{~cm}$ DBH were considered as small tree. Diameter of bamboo culms was measured at the middle part of the next internode if $1.37 \mathrm{~m}$ fell on node or near to node portion of culms. Basal diameter of shrubs and saplings were measured at $5 \mathrm{~cm}$ above the ground using a digital vernier calliper. Majority of the plant species were identified in the field and rest of the species which we could not reliably identify in the field were later identified referring Mizoram University Herbaria as well as other published literatures.

Dominant species of each site were identified based on their relative dominance (IVI). A group of dominant species (in order of their descending IVI) which together contributed $>35 \%$ of total relative dominance in a site were further studied for their species replacement along community succession.

\section{Biomass estimation}

Tree biomass was estimated using a diameter-only common allometric equation developed for mixed species tree biomass estimation in northeast India. A recent study by Nath et al. (2019) reported that the four commonly used generic models developed by Chambers et al. (2001), Brown et al. (1989), Chave et al. (2005), and Chave et al. (2014) overestimated biomass stocks by $300-591 \mathrm{~kg}$ tree $^{-1}$ in the northeast Indian condition. Although height is a valuable addition when estimating biomass, the diameter-only equation provides better biomass estimates than diameter-height allometry (Williams and Schreuder 2000). Therefore, to get accurate site specific estimation, we followed the diameter-only allometric model out of the two best fit models suggested by Nath et al. (2019). Biomass of shrubs and tree saplings was estimated using allometric equation developed by Ali et al. (2015). For deadwood biomass estimation, we followed the methodology suggested by Cros and Lopez (2009). Volume of the dead logs and stumps were first measured following the allometric equation developed by them. Stem length, diameter (mid), and decaying status of each fallen or standing deadwood piece were recorded in the field to estimate their volume. Then, the deadwood volume was multiplied by respective wood density values of different decaying status (freshly cut $=$ $0.48 \mathrm{~g} \mathrm{~cm}^{-3}$, moderately decomposed $=0.35 \mathrm{~g} \mathrm{~cm}^{-3}$, highly decomposed $=0.25 \mathrm{~g} \mathrm{~cm}^{-3}$, and burnt $=0.19 \mathrm{~g}$ $\mathrm{cm}^{-3}$ ) to estimate the deadwood biomass. Liana (Hairiah et al. 2011) and banana (Addo-Fordjour and Rahmad 2013) biomass was estimated using allometric equation developed for a similar ecological region. Biomass of the 
bamboo species present in the jhum fallows was estimated using allometric equation developed by Singnar et al. (2017) for northeast India. For litter and herb, all the standing biomass present in the quadrats was first measured in the field and 100-g fresh samples were brought to the laboratory for dry biomass estimation. Belowground biomass was estimated applying root to shoot ratio (0.24) which was suggested for the tropical rainforests having biomass production capacity of $>125$ $\mathrm{Mg} \mathrm{ha}^{-1}$ (Mokany et al. 2006). Biomass in all the compartments was finally extrapolated and scaled to per hectare basis.

\section{Carbon estimation}

Carbon content in herb and litter biomass was analyzed following dry ashing method (Campbell and Plank 1998) and then multiplied with the respective dry biomass amount. Biomass carbon in rest of the plant components was estimated by multiplying the default value of $47 \%$ with the total biomass amount (IPCC 2006). Soil organic carbon (SOC) concentration was determined by wet oxidation method (Walkley and Black 1934). The soils in the study area are purely acidic in nature (not calcareous). Therefore, we did not perform any acid pretreatment to remove carbonates before conducting the wet oxidation technique. Soil bulk density (BD) was measured using the method described by Brady and Weil (2008). SOC stock in different soil depths was computed by multiplying the respective $\mathrm{C}$ concentration (\%) with soil bulk density $\left(\mathrm{Mg} \mathrm{m}^{-3}\right)$ and soil depth $(\mathrm{m})$ using the following formula:

$$
\begin{aligned}
\mathrm{C} \operatorname{pool}\left(\mathrm{MgCha}^{-1}\right)= & \mathrm{C}(\%) \times \operatorname{bulk\operatorname {density}}\left(\mathrm{Mg} \mathrm{m}^{-3}\right) \\
& \times \operatorname{soil} \operatorname{depth}(\mathrm{m}) \times 10
\end{aligned}
$$

The total carbon stock in each site category was the sum of all the biomass compartments and the soil organic carbon.

\section{Recovery of species diversity, vegetation structure, and carbon stock}

To check how efficiently secondary forest may complement old-growth forest, recovery of species diversity, vegetation structure, and carbon stock was estimated in relation to the old-growth forest. For this, we referred the following equation suggested by Mukul et al. (2016).

$$
R=\left(X_{\text {fallow }} / X_{\mathrm{s}}\right) \times 100
$$

where $R$ is the recovery in percentage, $X_{\text {fallow }}$ is the measure of species diversity/vegetation structure/carbon stock values of each fallow category, and $X_{\mathrm{s}}$ is the mean value of the corresponding species diversity/vegetation structure/carbon stock parameters in old-growth forest sites.

\section{Statistical analysis}

Density, basal area, abundance, and importance value index (IVI) were calculated as per Misra (1968). Density and basal area were calculated from the expanded values of each nested subplot and represented as individuals per hectare and square meter per hectare basis. Species diversity indices such as Margalef's index of species richness $(M)$, Shannon's diversity index $(H)$, Simpson's dominance index $(C d)$, and species evenness index $(J)$ were calculated as per Magurran (2004).

Descriptive statistics were performed using SPSS version-20. Analysis of variance (ANOVA) and Tukey's post hoc test were performed to test the within and between significant differences of the different variables. To examine the effect of site environmental attributes on tree species diversity, vegetation structure, and carbon stock recovery, linear mixed effect models (LMEM) were developed using the R-package "nlme". We used fallow age (FA), distance from the old-growth forest (DOGF), slope (SL), patch size (PS), soil organic carbon (SOC) as fixed factors (i.e., explanatory variables), and carbon stocks in different components, tree structure attributes (i.e., density, basal area), and tree diversity indices (Simpson's dominance index, Shannon's diversity index, evenness index, Margalef's species richness index) were the dependent variables. To select the best LMEM, we considered Akaike information criterion corrected for small sample size (AICc) scores. The best models had the lowest AICc score. We used R-package "MuMin" for the model selection, and evaluated the contribution of different fixed effects to explaining the variation in the response variables (Bartón 2019).

\section{Results}

Species composition, richness, and diversity in jhum fallows and old-growth forest

Species composition varied significantly between the jhum fallows and old-growth forest. There was a gradual increase in species richness of trees with increase in jhum fallows which ranged from 13 to 40, but in the old-growth forest, tree species richness was 131. The species richness of both shrub and herb species was highest in young jhum fallows $(<5$ years old $)$ and their number showed a trend of gradual decrease with increased age of jhum fallows. The species richness of both shrub and herb was lowest in oldgrowth forest when compared to any of the jhum fallows (Table 1). In old-growth forest, the dominant trees were Castanopsis tribuloides, Calliandra umbrosa, and Litsea monoptera, while Callicarpa arborea, Albizia procera, and Trema orientalis in young jhum fallows ( $<5$ years old); Schima wallichii, Macaranga indica, Tectona grandis, and Macaranga denticulata in 6-10 years old jhum fallows; Callicarpa 
Table 1 Species richness of different communities in different aged jhum fallows and old-growth forest. Data are presented as mean \pm standard errors $(n=3)$

\begin{tabular}{|c|c|c|c|c|c|c|}
\hline Communities & Old-growth forest & $<5$ years old jhum & 5-10 years old jhum & 11-15 years old jhum & 16-20 years old jhum & $21-25$ years old jhum \\
\hline Tree & $131 \pm 14$ & $13 \pm 2$ & $16 \pm 3$ & $21 \pm 2$ & $26 \pm 5$ & $40 \pm 5$ \\
\hline Shrub & $8 \pm 2$ & $21 \pm 3$ & $19 \pm 2$ & $17 \pm 3$ & $15 \pm 4$ & $15 \pm 2$ \\
\hline Herb & $22 \pm 4$ & $45 \pm 6$ & $34 \pm 4$ & $30 \pm 7$ & $31 \pm 3$ & $24 \pm 3$ \\
\hline Liana & $10 \pm 0$ & - & - & - & $3 \pm 0$ & $6 \pm 0$ \\
\hline
\end{tabular}

arborea, Rhus chinensis, and Trema orientalis in 1115 years old jhum fallows; Callicarpa arborea, Mesua ferrea, and Albizia procera in 16-20 years old jhum fallows; and Litsea salicifolia, Duabanga grandiflora, Ficus bengalensis, and Bauhnia purporea in the oldest jhum fallow (21-25 years old) were the most dominant tree species (Additional file 1). The density of dominant trees gradually declined with the reduced age of the jhum fallows (Fig. 2). Chromolaena odorata, however, was invariably the most dominant shrub species in all the jhum fallows and old-growth forest. The other co-dominant shrubs were Melostoma malabathrium and Clerodendron viscosum in the jhum fallows and old-growth forest. Ageratum conyzoides, Christella parsitica, Curculigo crassifolia, and Diplazium esculentum were dominant herbs in old-growth forest, while some of these herbs were also represented in jhum fallows of different ages. The composition of herbs and shrubs was distinctly different under different jhum fallows when compared with the old-growth forest (Additional file 1). The plant diversity and structural attributes varied considerably among the jhum fallows. The density of trees varied from 27 stems $\mathrm{ha}^{-1}$ in $<5$ years old jhum fallows to 163 stems $\mathrm{ha}^{-1}$ in 20-25 years old jhum fallows and 880 stems $\mathrm{ha}^{-1}$ in old-growth forest (Table 2). The density of non-tree shrubby and herb species was higher in young jhum fallows and decreased with increasing age of jhum fallows. The non-tree shrub density ranged from 3050 individuals ha ha $^{-1}$ (20-25 years old jhum fallow) to 10,533 individuals ha ${ }^{-1}(<5$ years old jhum fallow), while the corresponding values for herbs were 67,291 and 148,541 respectively. Density of bamboo increased with increasing age of jhum fallows, while no bamboo species was encountered in the old-growth forest. Lianas were found in middleaged jhum fallows and its maximum density was observed in old-growth forest. Basal area of trees varied from $0.11 \mathrm{~m}^{2} \mathrm{ha}^{-1}$ in 5 years old jhum fallows to $11.19 \mathrm{~m}^{2} \mathrm{ha}^{-1}$ in 20-25 years old jhum fallows and $54.31 \mathrm{~m}^{2} \mathrm{ha}^{-1}$ in old-growth forest. The basal area of bamboo increased with the increasing age of jhum fallows. Unlike the trees and bamboos, the basal area of shrubs decreased with the increasing age of jhum fallows and was lowest in old-growth forest.
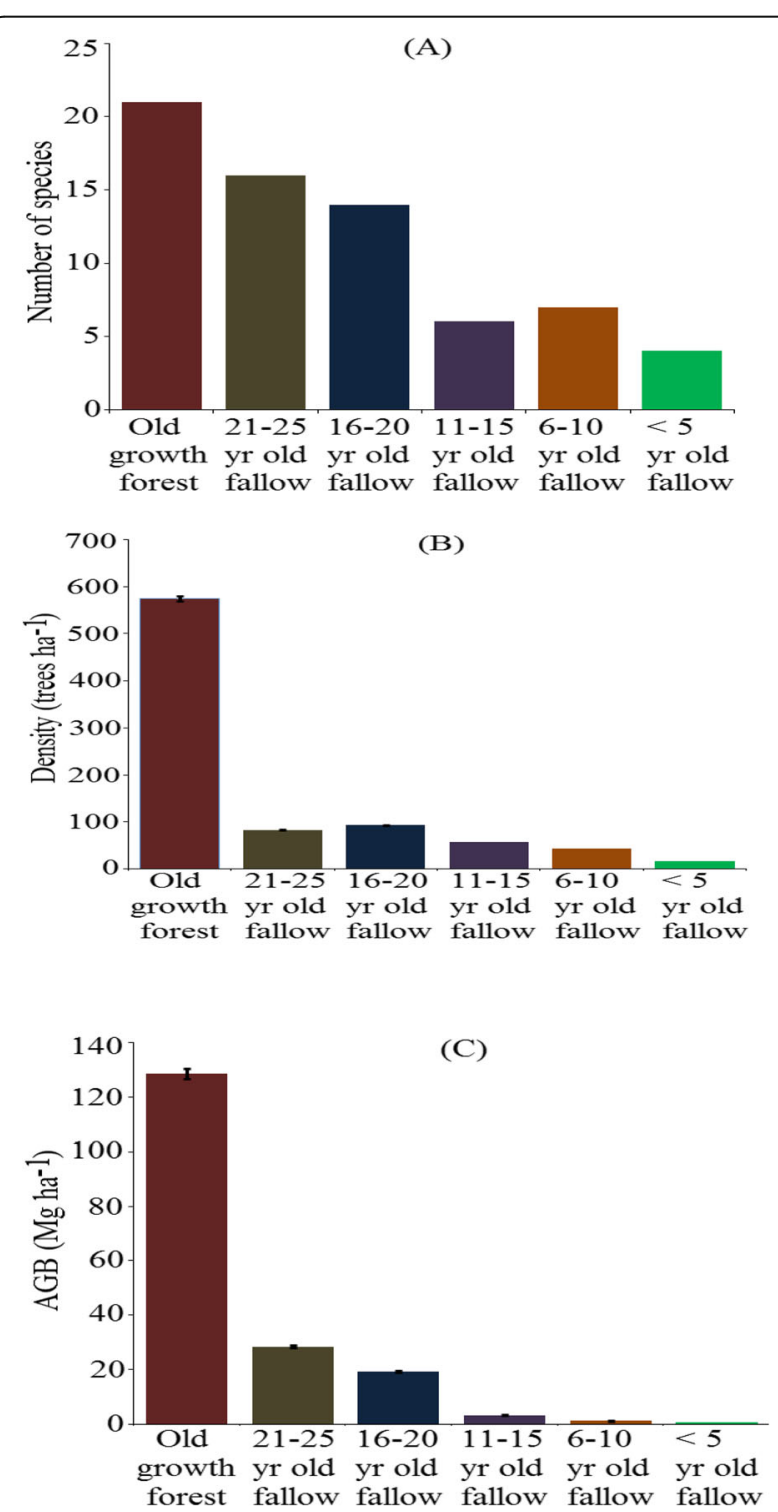

Fig. 2 The number (a), density (b), and aboveground biomass (AGB) (c) of dominant species in each jhum and old-growth forest (data are presented mean \pm standard error, $n=3$; vertical bar represents standard error). The dominant species are explained in Additional file 1. The symbols* $@$ @ \%, \#, \$, and @ represent dominant species in old-growth forest, 21-25 year old fallow, 16-20 year old fallow, 1115 year old fallow, 6-10 year old fallow, and $<5$ year old fallow respectively 
Table 2 Within and between variations of plant diversity and structural attributes across the differently aged jhum fallows and the old-growth forest

\begin{tabular}{|c|c|c|c|c|c|c|c|c|}
\hline \multicolumn{2}{|c|}{ Plant diversity and structural attributes } & \multicolumn{5}{|c|}{ Fallow category } & \multirow{2}{*}{$\begin{array}{l}\text { Old-growth } \\
\text { forest }\end{array}$} & \multirow{2}{*}{$\begin{array}{l}P \\
\text { value }\end{array}$} \\
\hline & & $\leq 5$ years old & $\begin{array}{l}6-10 \text { years } \\
\text { old }\end{array}$ & $\begin{array}{l}11-15 \\
\text { years old }\end{array}$ & $\begin{array}{l}16-20 \text { years } \\
\text { old }\end{array}$ & $\begin{array}{l}20-25 \text { years } \\
\text { old }\end{array}$ & & \\
\hline \multirow[t]{6}{*}{ Density (individuals ha ${ }^{-1}$ ) } & Tree & $27(6)^{a}$ & $59(2)^{a}$ & $99(3)^{b}$ & $129(12)^{b}$ & $163(4)^{b}$ & $880(51)^{c}$ & 0.001 \\
\hline & $\begin{array}{l}\text { Small tree }(<5 \mathrm{~cm} \\
\text { DBH) }\end{array}$ & $1200(210)$ & $2705(122)$ & $3590(534)$ & $4370(588)$ & $6030(600)$ & $9022(700)$ & 0.001 \\
\hline & Shrub (non-tree) & $10,533(1212)$ & $7816(258)$ & $6650(663)$ & $4050(332)$ & $3050(650)$ & $1216(187)$ & 0.001 \\
\hline & Liana & NP & NP & NP & $11(2)$ & $24(1)$ & $152(10)$ & 0.001 \\
\hline & Bamboo & $1326(123)$ & $1841(92)$ & $2670(115)$ & $3326(146)$ & $3710(60)$ & NP & 0.001 \\
\hline & Herb & $\begin{array}{l}148,541 \\
(4791)\end{array}$ & $\begin{array}{l}120,277 \\
(3095)\end{array}$ & $97,500(5962)$ & $90,208(2938)$ & $67,291(2916)$ & $\begin{array}{l}53,125 \\
(3083)\end{array}$ & 0.001 \\
\hline \multirow[t]{4}{*}{ Basal area $\left(\mathrm{m}^{2} \mathrm{ha}^{-1}\right)$} & Tree & $0.11(0.03)^{\mathbf{a}}$ & $0.49(0.27)^{\mathbf{a}}$ & $1.49(0.42)^{\mathbf{a}}$ & $5.42(0.15)^{\mathbf{b}}$ & $11.19(0.42)^{\mathbf{c}}$ & $\begin{array}{l}54.31 \\
(1.81)^{\mathbf{d}}\end{array}$ & 0.0 \\
\hline & Shrub & $1.25(0.17)$ & $1.01(0.11)$ & $0.78(0.09)$ & $0.64(0.13)$ & $0.41(0.02)$ & $0.35(0.04)$ & 0.001 \\
\hline & Liana & NP & NP & NP & 0.71 & 1.10 & 2.05 & 0.001 \\
\hline & Bamboo & $0.09(0.02)$ & $0.22(0.03)$ & $0.76(0.05)$ & $1.30(0.13)$ & $2.11(0.13)$ & NP & 0.04 \\
\hline \multirow{4}{*}{$\begin{array}{l}\text { Simpson's dominance } \\
\text { index }\end{array}$} & Tree & $0.21(0.07)$ & $0.15(0.03)$ & $0.09(0.00)$ & $0.09(0.01)$ & $0.07(0.00)$ & $0.02(0.00)$ & 0.02 \\
\hline & Shrub & $0.11(0.02)$ & $0.09(0.01)$ & $0.09(0.01)$ & $0.13(0.01)$ & $0.11(0.01)$ & $0.24(0.02)$ & 0.001 \\
\hline & Liana & NP & NP & NP & $0.51(0.01)$ & $0.34(0.03)$ & $0.28(0.02)$ & 0.001 \\
\hline & Herb & $0.03(0.00)$ & $0.05(0.01)$ & $0.05(0.00)$ & $0.05(0.01)$ & $0.08(0.01)$ & $0.11(0.01)$ & 0.001 \\
\hline \multirow[t]{4}{*}{ Shannon's diversity index } & Tree & $1.69(0.33)$ & $1.99(0.24)$ & $2.40(0.04)$ & $2.46(0.05)$ & $2.69(0.08)$ & $4.20(0.08)$ & 0.001 \\
\hline & Liana & NP & NP & NP & $0.92(0.29)$ & $0.68(0.01)$ & $1.46(0.07)$ & 0.05 \\
\hline & Shrub & $2.24(0.15)$ & $2.47(0.11)$ & $2.35(0.06)$ & $1.57(0.55)$ & $2.21(0.08)$ & $1.45(0.08)$ & 0.05 \\
\hline & Herb & $3.43(0.02)$ & $3.11(0.17)$ & $3.01(0.05)$ & $3.01(0.10)$ & $2.63(0.12)$ & $2.26(0.12)$ & 0.001 \\
\hline \multirow[t]{4}{*}{ Evenness index } & Tree & $0.99(0.01)$ & $0.98(0.01)$ & $0.99(0.01)$ & $0.99(0.00)$ & $0.99(0.01)$ & $0.97(0.00)$ & 0.13 \\
\hline & Liana & NP & NP & NP & $0.99(0.00)$ & $0.75(0.21)$ & $1.00(0.00)$ & 0.33 \\
\hline & Shrub & $0.98(0.01)$ & $0.99(0.00)$ & $0.99(0.00)$ & $0.74(0.25)$ & $0.99(0.00)$ & $0.99(0.00)$ & 0.47 \\
\hline & Herb & $0.99(0.00)$ & $0.98(0.00)$ & $0.99(0.00)$ & $0.99(0.00)$ & $0.98(0.00)$ & $0.98(0.01)$ & 0.001 \\
\hline \multirow[t]{4}{*}{ Margalef's index } & Tree & $2.04(0.57)$ & $2.22(0.64)$ & $2.81(0.08)$ & $2.81(0.21)$ & $3.43(0.36)$ & $12.67(0.67)$ & 0.001 \\
\hline & Liana & NP & NP & NP & $0.72(0.10)$ & $1.04(0.13)$ & $0.81(0.7)$ & 0.15 \\
\hline & Shrub & $1.68(0.25)$ & $2.24(0.28)$ & $1.98(0.14)$ & $1.68(0.23)$ & $2.05(0.04)$ & $1.05(0.06)$ & 0.01 \\
\hline & Herb & $5.73(0.13)$ & $4.44(0.73)$ & $3.96(0.21)$ & $4.08(0.45)$ & $2.99(0.36)$ & $2.11(0.33)$ & 0.001 \\
\hline
\end{tabular}

NP not present

Values in parentheses are standard errors of mean. Data showing the same letters are not statistically significant with each other $(\mathrm{DF}=5)$

Simpson dominance index for trees decreased gradually along succession of jhum fallows and was lowest in old-growth forest, and the reverse trend was observed for herbaceous species, while shrubby species did not show any clear trend on Simpson dominance index along succession of jhum fallow though the value was highest in old-growth forest. Shannon's diversity index for trees and herbs showed gradual increase with increasing age of jhum fallows and had highest value in old-growth forest (Table 2), while shrubby species did not show any clear trend. Evenness index for all the communities remained almost similar across the jhum fallows and remained comparable with the old-growth forest. Margalef's index for trees gradually increased with the increasing age of jhum fallows, while it showed a decreasing pattern for herbs.

Biomass carbon in jhum fallows and old-growth forest Carbon accumulation in various pools in different jhum fallows is shown in Table 3 . The living woody aboveground biomass carbon was highest in the oldest jhum fallow (30.32 $\mathrm{Mg} \mathrm{ha}^{-1}$ ) and lowest in youngest jhum fallow $\left(1.41 \mathrm{Mg} \mathrm{ha}^{-1}\right)$. The reverse pattern was found for the living non-woody aboveground biomass carbon. The coarse deadwood biomass carbon was highest in youngest jhum fallow $\left(0.46 \mathrm{Mg} \mathrm{ha}^{-1}\right)$ and it gradually declined with the increasing age of the jhum fallow. The oldgrowth forest had the highest value of living woody 
Table 3 Within and between variations of carbon pools $\left(\mathrm{Mg} \mathrm{ha}^{-1}\right)$ across the differently aged jhum. The values in the parentheses are standard error of mean. The values between rows with shared superscripts are not significantly different $(P<0.01)$ based on pair-wise comparison

\begin{tabular}{|c|c|c|c|c|c|c|c|}
\hline \multirow{2}{*}{$\begin{array}{l}\text { Carbon } \\
\text { components }\end{array}$} & \multicolumn{5}{|c|}{ Fallow category } & \multirow{2}{*}{$\begin{array}{l}\text { Old-growth } \\
\text { forest }\end{array}$} & \multirow{2}{*}{$\begin{array}{l}P \\
\text { value }\end{array}$} \\
\hline & $\leq 5$ years old & 6-10 years old & $11-15$ years old & 16-20 years old & $20-25$ years old & & \\
\hline LWAGBC & $1.41(0.24)^{\mathbf{a}}$ & $3.13(0.88)^{\mathbf{a}}$ & $6.06(0.89)^{\mathbf{a}}$ & $16.94(0.54)^{\mathbf{b}}$ & $30.32(0.69)^{\mathbf{c}}$ & $146.15(6.36)^{\mathbf{d}}$ & 0.001 \\
\hline LWBGBC & $0.34(0.06)^{\mathbf{a}}$ & $0.75(0.21)^{\mathbf{a}}$ & $1.46(0.21)^{\mathbf{a}}$ & $4.07(0.13)^{\mathbf{b}}$ & $7.28(0.17)^{c}$ & $35.08(1.53)^{\mathbf{d}}$ & 0.001 \\
\hline LNWAGBC & $4.08(0.13)^{\mathbf{a}}$ & $3.23(0.12)^{\mathbf{b}}$ & $2.41(0.17)^{c}$ & $1.68(0.08)^{\mathbf{d}}$ & $1.33(0.13)^{\mathbf{e}}$ & $0.92(0.06)^{\mathbf{f}}$ & 0.001 \\
\hline LNWBGBC & $0.80(0.02)^{\mathbf{a}}$ & $0.66(0.02)^{\mathbf{b}}$ & $0.52(0.03)^{c}$ & $0.34(0.02)^{\mathbf{d}}$ & $0.28(0.03)^{\mathbf{e}}$ & $0.18(0.02)^{\mathbf{f}}$ & 0.00 \\
\hline $\mathrm{CDBC}$ & $0.46(0.07)^{\mathbf{a}}$ & $0.41(0.01)^{\mathbf{a}}$ & $0.32(0.03)^{\mathbf{a}}$ & $0.23(0.05)^{\mathbf{a}}$ & $0.12(0.02)^{\mathbf{a}}$ & $2.70(0.86)^{\mathbf{b}}$ & 0.00 \\
\hline LBC & $0.04(0.01)^{\mathbf{a}}$ & $0.12(0.03)^{\mathbf{a}}$ & $0.26(0.02)^{\mathbf{a}}$ & $0.53(0.06)^{\mathbf{b}}$ & $0.79(0.08)^{c}$ & $2.91(0.19)^{d}$ & 0.001 \\
\hline soc & $14.91(4.34)^{\mathbf{a}}$ & $21.96(0.35)^{\mathbf{a}}$ & $25.70(0.82)^{\mathbf{b}}$ & $31.60(0.88)^{\mathbf{b}}$ & $48.38(4.28)^{\mathbf{c}}$ & $77.69(5.30)^{\mathbf{d}}$ & 0.001 \\
\hline TAGC & $6.00(0.42)^{\mathbf{a}}$ & $6.90(0.77)^{\mathbf{a}}$ & $9.06(0.85)^{\mathbf{a}}$ & $19.38(0.48)^{\mathbf{b}}$ & $32.55(0.86)^{\mathbf{c}}$ & $152.68(6.60)^{\mathbf{d}}$ & 0.001 \\
\hline TBGC & $16.04(4.27)^{\mathbf{a}}$ & $23.37(0.54)^{\mathbf{a}}$ & $27.67(0.99)^{\mathbf{b}}$ & $36.00(0.97)^{c}$ & $55.93(4.15)^{\mathbf{d}}$ & $112.94(4.53)^{\mathbf{e}}$ & 0.0 \\
\hline TEC & $22.04(3.85)^{\mathbf{a}}$ & $30.26(1.30)^{\mathbf{a}}$ & $36.73(1.80)^{\mathbf{b}}$ & $55.39(1.36)^{c}$ & $88.48(3.70)^{\mathbf{d}}$ & $265.63(5.82)^{\mathbf{e}}$ & 0.0 \\
\hline
\end{tabular}

$\angle W A G B C$ living woody aboveground biomass carbon, $\angle W B G B C$ living woody belowground biomass carbon, $L N W A G B C$ living non-woody aboveground biomass carbon, $L N W B G B C$ living non-woody belowground biomass carbon, $C D W B C$ coarse deadwood biomass carbon, $\angle B C$ litter biomass carbon, SOC soil organic carbon, TAGC total aboveground carbon, TBC total belowground carbon, TEC total ecosystem carbon

aboveground biomass carbon and coarse deadwood biomass carbon compared to the jhum fallows; however, living non-woody biomass carbon was quite low in oldgrowth forest compared to the jhum fallows. The dominant tree species contributed more than $50 \%$ to the total aboveground biomass of each jhum fallow except the two younger jhum fallows (Fig. 2). Soil organic carbon (SOC) showed a progressive increase with the increasing age of jhum fallows and ranged from $14.91 \mathrm{Mg}$ $\mathrm{ha}^{-1}$ (youngest jhum fallow, < 5 years old) to $48.38 \mathrm{Mg}$ $\mathrm{ha}^{-1}$ (oldest jhum fallows) and was highest $(77.69 \mathrm{Mg}$ $\mathrm{ha}^{-1}$ ) in old-growth forest. The SOC was higher in deeper soil layer $(30-45 \mathrm{~cm})$ than in surface soil layer $(0-15 \mathrm{~cm})$. Soil organic carbon contributed maximally to the total ecosystem carbon (TEC) in younger jhum fallows, while the trees contributed maximally to the TEC in the old-growth forest (Fig. 3). The contribution of shrubs and herbs was relatively higher in the young jhum fallows than the older fallows. Coarse deadwood carbon contribution was more in the

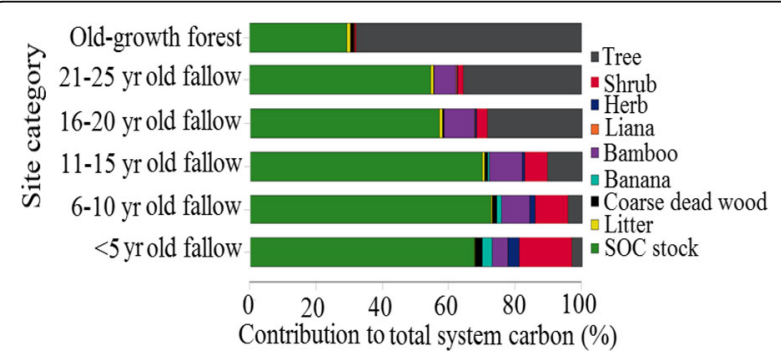

Fig. 3 Contributions of different carbon components to their corresponding total ecosystem carbon stock in the study sites two younger jhum fallows and gradually reduced with increase in age of jhum fallows. Banana contribution to the TEC was higher in the youngest jhum fallow. Distribution of SOC in different soil depths varied significantly across the jhum fallows (Fig. 4). SOC showed a gradual increase with the increase in soil depth in all the jhum fallows as well as old-growth forest. However, SOC was comparable between different jhum fallows at a given soil depth, with no clear successional trend being observed.

\section{Recovery of vegetation and biomass carbon}

When compared to old-growth forest, tree diversity and basal area gradually recovered with the increasing fallow age. TEC recovery ranged from $8 \%$ in $<5$ years old jhum fallow to $33 \%$ in oldest jhum fallow (Table 3). SOC pool recovered much faster compared to other carbon pools and the SOC stock of the oldest jhum fallow (20-25 years old) was $62 \%$ of that of the old-growth forest. SOC stock

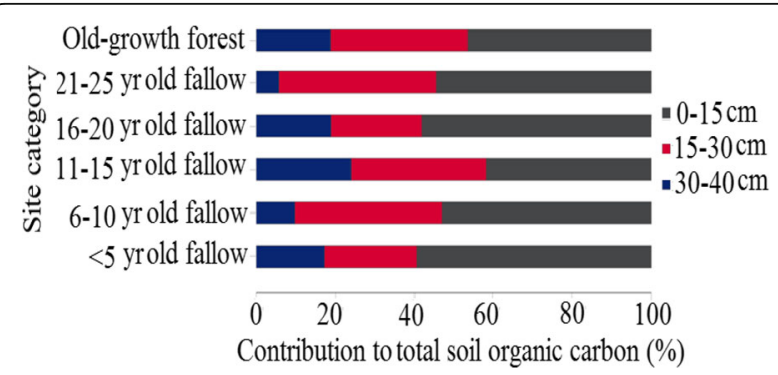

Fig. 4 Distribution of soil organic carbon stocks (SOC) along the soil depths in the study sites. The values are percentage contribution to their corresponding total SOC stock $(0-45 \mathrm{~cm}$ soil depth) 
recovery gradually increased with increasing fallow age (Fig. 5).

Factors affecting vegetation and carbon stock recovery Factors influencing different fractions of biomass carbon, vegetation, and ecological indices and their relative importance (Table 4) revealed that the fallow age was the most important factor in contributing to all parameters of measurement except Pileou's evenness index. SOC had maximum effect on basal area and coarse deadwood biomass carbon, while patch size (area covered by a jhum field) had relatively higher effect on
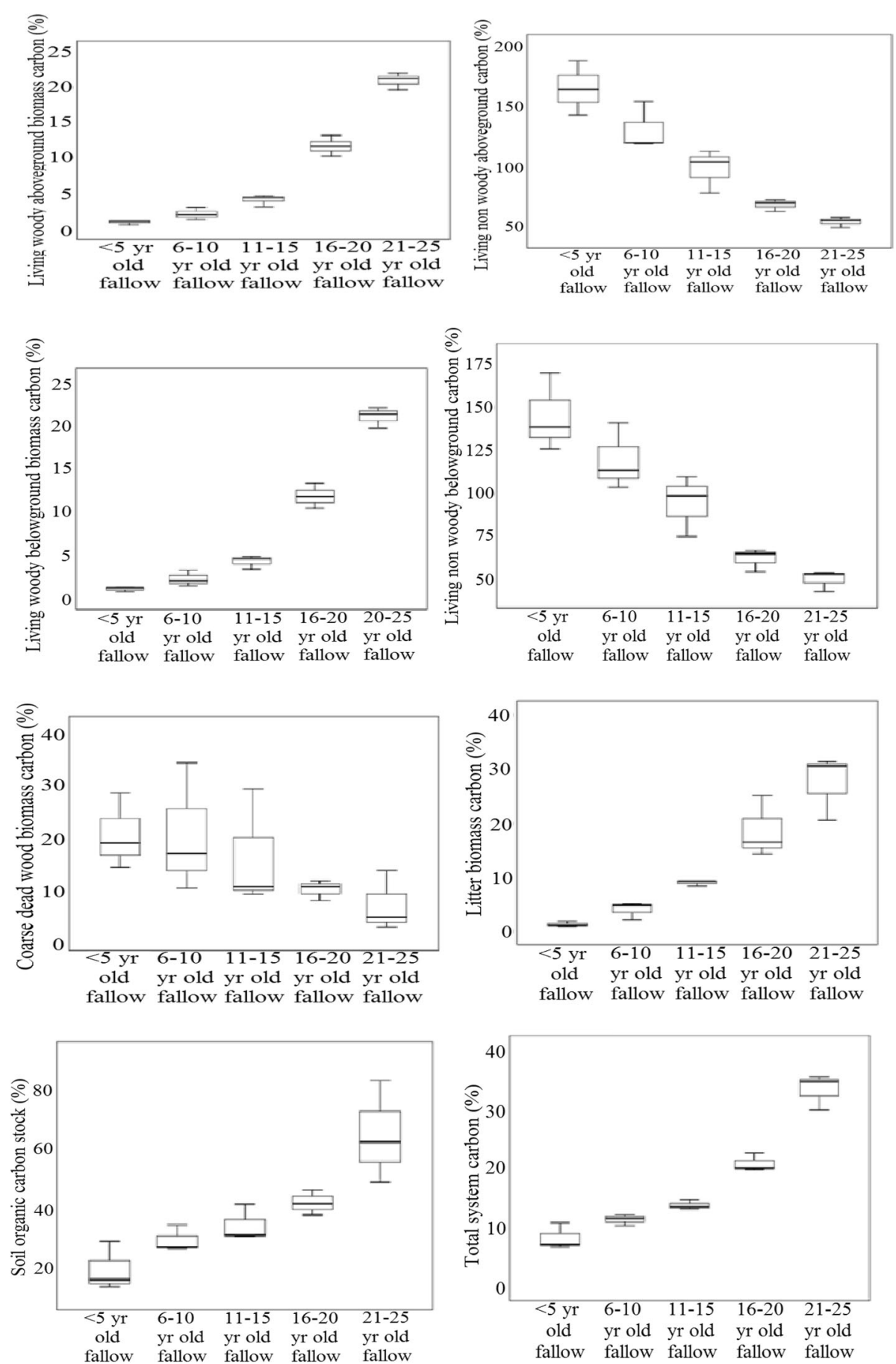

Fig. 5 Carbon stock recovery in different components of the jhum fallows relative to old-growth forest in the study area. Each bar represents upper, median, and lower values of carbon recovery and standard deviation of each corresponding fallow category 
Table 4 The relative importance of the site environmental attributes in the final linear mixed effect models (LMEM)

\begin{tabular}{lllllll}
\hline Parameter & \multicolumn{2}{l}{ Explanatory variables } & & $\begin{array}{l}\text { Number } \\
\text { of } \\
\text { models }\end{array}$ \\
\cline { 2 - 5 } & FA & DOGF & SL & PS & SOC & \\
\hline LNWBC & $1.00(15)$ & $0.21(7)$ & $0.11(7)$ & $0.15(7)$ & $0.30(7)$ & 15 \\
LWBC & $1.00(14)$ & $0.15(6)$ & $0.10(6)$ & $0.11(6)$ & $0.71(7)$ & 14 \\
CDWBC & $0.97(14)$ & $0.18(14)$ & $0.20(14)$ & $0.27(14)$ & $0.56(14)$ & 30 \\
LBC & $1(15)$ & $0.04(6)$ & $0.15(7)$ & $0.15(7)$ & $0.19(7)$ & 15 \\
SOCS & $0.99(14)$ & $0.25(8)$ & $0.12(7)$ & $0.11(7)$ & $0.12(70$ & 19 \\
Density & $0.83(10)$ & $0.12(6)$ & $0.09(6)$ & $0.76(7)$ & $0.11(6)$ & 14 \\
BA & $0.97(15)$ & $0.19(16)$ & $0.14(16)$ & $0.10(16)$ & $0.59(16)$ & 32 \\
SDI & $0.89(16)$ & $0.31(16)$ & $0.13(16)$ & $0.34(16)$ & $0.11(16)$ & 32 \\
SWDI & $0.83(15)$ & $0.36(16)$ & $0.12(16)$ & $0.33(16)$ & $0.11(16)$ & 32 \\
PEI & $0.13(16)$ & $0.21(16)$ & $0.15(16)$ & $0.13(16)$ & $0.19(16)$ & 32 \\
MSRI & $0.58(16)$ & $0.33(16)$ & $0.11(16)$ & $0.23(15)$ & $0.14916)$ & 32
\end{tabular}

$\angle W B C$ living woody biomass carbon, $\angle N W B C$ living non-woody biomass carbon, $C D W B C$ coarse deadwood biomass carbon, $L B C$ litter biomass carbon, $S O C$ soil organic carbon, $B A$ basal area, SDI Simpson's dominance index, SWDI Shannon's diversity index, PEI Pielou's evenness index, MSRI Margalef's species richness index, FA fallow age, DOGF distance from the old-growth forest, $S L$ slope, PS patch size, SOC soil organic carbon

density, similarity index, and diversity index. The distance from the old-growth forest had low importance on biomass and carbon recovery, while it had high importance on diversity and species richness index.

\section{Discussion}

\section{Community succession}

The remnant rainforests of the region are subjected to various kinds of disturbance (Gogoi and Sahoo 2018) and the practice of jhum is the most dominating factor affecting the biodiversity and potential of these forests to contribute to livelihoods and other ecosystem services. Our study revealed that species diversity and composition in the jhum fallows remained distinctly different from that of old-growth forest. However, the structure of secondary communities on jhum fallows gradually becomes more complex with the increasing age of the jhum fallows. The Shannon and Margalef indices for trees gradually increased along the successional jhum fallows and showed highest value for the old-growth forest. This indicates that both species richness and evenness of this community increased with increasing age of jhum fallows. The decreasing trend of Shannon and Margalef indices for herbaceous species along the successional jhum fallows reveal their reduced diversity, related to unfavourable spatio-temporal micro-niche availability as the jhum cycle progressed (Tilman and Pacala 1993). Plant species richness in 20-40 years old jhum fallow has been reported to recover to the values compared to that of mature forest; however, species composition recovery may take several decades (N'Dja et al. 2008; Rozendaal et al. 2019). The increase in species similarity between the secondary forests and the old-growth forest support the view of equilibrium succession dynamics (Huang et al. 2012). In the present study, in 25 years' time, tree and liana species recovery could reach $30 \%$ and $60 \%$ respectively, of the old-growth forest. Thong et al. (2016) reported recovery of trees and shrub species by $35.9 \%$ and $24.4 \%$ respectively during a 20 -year jhum succession. The variations in the vegetation assemblage/communities across the jhum fallows could be related to several factors such as edaphic factors (Mishra and Ramakrishnan 1983; Brown and Lugo 1990), competitions (Tilman 1982, Ashton 1989), and remnant vegetation (Finegan and Delgado 2000; Guariguata and Ostertag 2001). The herbaceous and other shrubby species in the younger jhum fallows were quite conspicuous. This suggests that the succession of pioneer vegetation following suspension of shifting cultivation occurred rapidly in the early stages of succession while woody biomass recovery got delayed (Ulh 1987, Toky and Ramakrishnan 1983, Saxena and Ramakrishnan 1984). The early colonizers such as bamboo and banana were found to be dominant in jhum fallows as old as 10 years. Relatively faster growth of these species compared to woody species can facilitate soil-nutrient recovery and provide better micro-habitat for regeneration of other shade-loving tree species (Rao and Ramakrishnan 1989).

\section{Dominant tree species replacement and carbon stock in plant and soil}

Several tree species (Callicarpa arborea, Albizia procera, Bauhnia variegata, Artocarpus chaplasha, Glochidion heyneanum, Macaranga indica, Syzygium kurzii, Toona ciliata, Trema orientalis) dominated in the early successional jhum fallows were replaced by other trees (Rhus chinensis, Anthocephalus chinensis, Macaranga peltata, Bombax ceiba, Phoebe hainesiana, Parkia timoriana, Ficus altissima, Lagerstroemia speciosa) in the midsuccessional jhum fallows and by Castonopsis tribuloides, Calliandra umbrosa, Mesua ferrea, Schima wallichii, and Listea salicifolia in the late successional jhum/oldgrowth forest. The proportion of dominant tree species in old-growth community was lower than that of secondary forests. These findings clearly reveal the disturbance interrupted the competitive process maintaining the early successional tree species in the forest community (Parrish and Bazzaz 1982; Pickett et al. 1989; Yamamoto 2000) and with gradual species replacement by species that are apparently shade-tolerant/climax species (Additional file 1). These consequently affected the plant and soil carbon stock. Higher accumulation of carbon in both plant and soil with increasing restoration periods was obviously due to larger trees in successive jhum 
fallows. Thus, the regenerating secondary forests could provide co-benefits not only for carbon but also for biodiversity (Gilroy et al. 2014; Mukul et al. 2016). The regrowth forests therefore could be important for in-situ conservation of tropical biodiversity which may serve as buffer zones around fragmented old-growth forests (Yirdaw et al. 2019).

\section{Effect of jhum fallow recovery on region carbon sink}

The results reveal rapid recovery of aboveground biomass carbon during early successional stages after abandonment while relatively slow recovery of this carbon pool was observed at mid-successional jhum fallow and old-growth forest. Among the secondary successions of jhum fallows, soil carbon considerably increased from $14.91 \mathrm{Mg} \mathrm{ha}^{-1}$ in 5 years old fallow to $48.38 \mathrm{Mg} \mathrm{ha}^{-1}$ in 21-25 years old jhum fallow. Aboveground living tree biomass was highest in oldest jhum fallow, while coarse deadwood biomass was high in new fallow sites compared to old-growth forest. The undergrowth and litter biomass carbon gradually increased from the new site to old forest site. The total aboveground carbon (woody, non-woody, coarse deadwood, and litter biomass carbon) increased from $6.0 \mathrm{Mg} \mathrm{ha}^{-1}$ in the youngest jhum fallow (5 years old) to $32.55 \mathrm{Mg} \mathrm{ha}^{-1}$ in oldest jhum fallow (2125 years old). SOC increased with the age of the fallow from $14.91 \mathrm{Mg} \mathrm{ha}^{-1}$ in 5 years old jhum fallow to 77.69 $\mathrm{Mg} \mathrm{ha}^{-1}$ in oldest jhum fallow (21-25 years old). The pattern of carbon recovery across different jhum fallows indicates that secondary forest can serve as a carbon sink if allowed to continue without further disturbance. The living woody aboveground biomass carbon recovered by $21 \%$ in the oldest jhum fallow, while better recovery $(62 \%)$ in SOC stock was attained in this fallow during 25 years period.

\section{Difference of results in this study from others}

Substantial recovery of carbon stock was observed as secondary forests developed and it varied with the age of secondary forests, as shown by other studies of recovery of shifting cultivation in tropical forests (Pelletier et al. 2012, Chan et al. 2016). Many studies have found that the secondary forests can reach one-half of the levels of aboveground biomass in old-growth forests within 30year period (D'oliveira et al. 2011; Gilroy et al. 2014; Mukul et al. 2016; Salinas-Melgoza et al. 2017; Borah et al. 2018). In our study, we found that 25 -year fallow attained a recovery of living woody aboveground biomass carbon, SOC and total ecosystem carbon of $21 \%$, $33 \%$, and $62 \%$ of the old-growth forest respectively. However, much faster recovery of biomass $(50 \%)$ of the old-growth forest was reported within a span of 12-25 years of succession (Read and Lawrence 2003) and attained same level of that of old-growth forest within
20 years (Salinas-Melgoza et al. 2017) in dry tropical forests. The old-growth forest carbon stocks in tropical mountains of Asia with minimal anthropogenic disturbances reported are $321.29 \mathrm{Mg} \mathrm{ha}^{-1}$ (Mukul et al. 2016), $355.09 \mathrm{Mg} \mathrm{ha}^{-1}$ (Joshi et al. 2013), and $376.6 \mathrm{Mg} \mathrm{ha}^{-1}$ (Zhang et al. 2013). The total ecosystem carbon in the present study (22.04-88.48 $\left.\mathrm{Mg} \mathrm{ha}^{-1}\right)$ is comparable to those reported in Myanmar (5.70-167.77 ha ${ }^{-1}$ ) with similar fallow age group (Chan et al. 2016).

\section{Conclusions}

Our study provides a better insight on the pattern of recovery of vegetation and carbon stock with forest succession. The increased species richness and diversity along the successive jhum fallows evince the scope for enhancement of biodiversity enriched services and may help in forest-based economies. Total ecosystem carbon stock increases in the latest stages of succession, which suggests the potential role of secondary forests in restoring carbon following abandonment of shifting cultivation. The enhancement of carbon stored in the woody vegetation as the succession progresses further suggests that the practice of shifting cultivation can be sustainable if the fallow periods are relatively long and therefore the jhum policy should specifically consider conservation of secondary/regrowth forest in restoration of biodiversity and carbon stock.

\section{Supplementary information}

Supplementary information accompanies this paper at https://doi.org/10. 1186/s13717-020-00225-w.

Additional file 1 Density ( $D=$ Number of individual $h^{-1}$ ) and

importance value index (IVI) of different species in jhum fallows and oldgrowth forests. (-) indicates species absence.

\section{Abbreviations}

AIC: Akaike information criterion; BA: Basal area; BD: Bulk density; CDWBC: Coarse deadwood biomass carbon; D: Density; DBH: Diameter at breast height; DF: Degree of freedom; DOGF: Distance from the old-growth forest; FA: Fallow age; iNDC: Intended Nationally Determined Contribution; IPCC: International Panel on Climate Change; IVI: Importance value index; LBC: Litter biomass carbon; LL: Log likelihood; LWBC: Living woody biomass carbon; LNWBC: Living non-woody biomass carbon; LMEM: Linear mixed effects model; MSRI: Margalef's species richness index; PEl: Pielou's evenness index; PS: Patch size; SOC: Soil organic carbon; SPSS: Statistical Package for Social Sciences; SDI: Simpson's dominance index; SL: Slope; SWDI: Shannon's diversity index; TAGC: Total aboveground carbon; TBC: Total belowground carbon; TEC: Total ecosystem carbon; UNFCCC: UN Framework Convention on Climate Change; WWF: World Wide Fund

\section{Acknowledgements}

We thank all the "jhum" farmers who permitted us to work in their lands, and the Department of Environment, Forests and Climate Change for granting permission to work around the Dampa Tiger Reserve of Mizoram. We also thank the two anonymous reviewers for their insightful comments and suggestions, and for improving the paper.

Authors' contributions

AG and UKS formulated the research and designed sampling methods; UKS obtained funding and supervised the work; AG carried out the field work; 
and AG, UKS, and HS analyzed the data. All authors revised and approved the manuscript.

\section{Funding}

This study was financially supported by DST, Government of India (Sanction No. DST/IS STAC/CO2-SR-227/14(G)-AICP-AFOLU-IV).

\section{Availability of data and materials}

All data are available with this as supplementary files. Additional data can be available from the corresponding author upon reasonable request.

\section{Ethics approval and consent to participate}

Not applicable

\section{Consent for publication}

Not applicable

\section{Competing interests}

The authors declare that they have no competing interests.

\section{Author details}

${ }^{1}$ Department of Forestry, Mizoram University, Aizawl 796004, India. ${ }^{2}$ College of Sericulture, Assam Agricultural University, Jorhat 785013, India.

\section{Received: 7 November 2019 Accepted: 20 March 2020}

Published online: 07 May 2020

\section{References}

Addo-Fordjour P, Rahmad ZB (2013) Mixed species allometric models for estimating above-ground liana biomass in tropical primary and secondary forests, Ghana. ISRN Forestry, article ID-153587

Ali A, Xu M-S, Zhao Y-T, Zhang Q-Q (2015) Allometric biomass equations for shrub and small tree species in subtropical China. Silva Fennica 49(4):1-10

Ashton PS (1989) Species richness in tropical forests. In: Holm-Neilsen et al (eds) Tropical Forests. Academic Press, London, pp 239-251

Badalamenti E, Battipaglia G, Gristina L, Novaro A, Ruhl J, Sala G, Sapienza L (2019) Carbon stock increases up to old growth forest along a secondary succession in Mediterranean island ecosystems. PLoS One 14(7):e0220194

Bandy DE, Garrity DP, Sanchez PA (1993) The worldwide problem of slash-andburn agriculture. Agric Today 5:2-6

Bartón K (2019) Package 'MuMIn' Available online at: http://cran.r-project.org/ web/packages/MuMln.pdf. (Date of access: 1/11/2019)

Borah JR, Evan KL, Edwards D (2018) Quantifying carbon stocks in shifting cultivation landscapes under different management scenarios relevant to REDD+. Ecol Appl 28(6):1581-1593

Brady NC (1996) Alternatives to slash-and-burn: a global imperative. Agric Ecosyst Environ 58:3-11

Brady NC, Weil RR (2008) The Nature and properties of soil, 14th edn. Pearson Prentice Hall, New Jersey

Brown S, Gillepsi AJR, Lugo AE (1989) Biomass estimation methods for tropical forests with application to forests inventory data. For Sci 35:881-902

Brown S, Lugo AE (1990) Tropical secondary forests. J Trop Ecol 6:1-32

Campbell CR, Plank CO (1998) Preparation of plant tissues for laboratory analysis. In: Kalra YP (ed) Handbook of Reference Methods for plant analysis. CRC Press, Boca Raton, pp 37-49

Chambers JQ, Santos JD, Riberiro RJ, Higuchi N (2001) Tree damage, allometric relationships and above-ground net primary production in Central Amazon forest. For Ecol Manage 132:73-84

Champion HG, Seth SK (1968) The forest types of India, New Delhi

Chan N, Takeda S, Suzuki R, Yamamoto S (2016) Assessment of biomass recovery and soil carbon storage of fallow forests after swidden cultivation in the Bago Mountains, Myanmar. New Forests 47:565-585

Chave J, Andalo C, Brown S, Cairns MA, Chambers JQ, Eamus J, Folster H, Fromard F, Higuchi N, Kira T et al (2005) Tree allometry and improved estimation of carbon stocks and balance in tropical forests. Oecologica 145:87-99

Chave J, Rejou-Mechain M, Burquez A, Chidumayo E, Colgan MS, Delitti WBC, Duque A, Eid T, Fearnside PM, Goodman RC, Henry M et al (2014) Improved allometric models to estimate the aboveground biomass of topical forest trees. Glob Change Biol 20:3177-2190
Cros RTD, Lopez S (2009) Preliminary study on the assessment of deadwood volume by the French national forest inventory. Ann Forest Sci 66(3):302. https://doi.org/10.1051/forest/2009007

D'oliveira MVN, Alvarado EC, Santos JC, Carvalho JA (2011) Forest natural regeneration and biomass production after slash and burn in a seasonally dry forest in the Southern Brazilian Amazon. For Ecol Manage 261:1490-1498

Erni C (2009) Shifting the blame? Cultivation in age of climate change, pp 38-49

Fearnside PM, Guimaraes WM (1996) Carbon uptake by secondary forests in Brazilian Amazonia. For Ecol Manage 80(13):35-46

Fergusan BG, Vandeermeer J, Morales H, Griffith DM (2001) Post-agricultural sucesssion in El-Peten, Guatemala. Conserv Biol 17:818-828

Finegan B, Delgado D (2000) Structural and floristic heterogeneity in a 30-year old Cost-Rican rain forest restored on pasture through natural secondary succession. Restor Ecol 8:380-393

Fox J, Castella JC, Ziegler AD (2014) Swidden, rubber and carbon: can REDD+ work for people and the environment in Montane Mainland Southeast Asia? Global Environ Change 29:318-326

Gilroy JJ, Woodcock P, Edwards FA, Wheeler C, Uribe CAM, Haugaasen T, Edwards DP (2014) Optimizing carbon storage and biodiversity protection in tropical agricultural landscapes. Glob Change Biol 20:2162-2172

Gogoi A, Sahoo UK (2018) Impact of anthropogenic disturbance on species diversity and vegetation structure of a lowland rainforest of eastern Himalaya, India. J Mt Sci 15(11):2453-2465

Griffiths T (2008) Seeing "REDD"? Forests, climate change mitigation and the rights of indigenous peoples and local communities: update for Poznan (UNFCCC COP 14), December.

Guariguata MR, Ostertag R (2001) Neotropical secondary forest succession: changes in structural and functional characteristics. For Ecol Manage 148: $185-206$

Hairiah K, Devi S, Agus F, Velarde S, Ekadinata A, Rahagu S, Noordwijk MV (2011) Measuring carbon stock across land use systems. A manual. World Agroforestry Centre (ICRAF), SEA Regional Office, Bogor

Huang Y-F, Ding Y, Zang R-G, Li X-C, Zou Z-C, Han W-T (2012) Spatial pattern of trees in tropical lowland rain forest in Bawangling of Hainan Island. Chin J Plan Ecol 36(4):269-280

Ickowitz A (2006) Shifting cultivation and deforestation in tropical Africa: critical reflections. Develop Change 37:599-626

IPCC (2006) 2006 IPCC Guidelines for National Greenhouse Gas Inventories. Available at http://www.ipcc.nggip.iges.or.jp/public/2006gl/

Joshi NR, Tewari A, Chand DB (2013) Impact of forest fire and aspects on phytosociology, tree biomass and carbon stock in oak and pine mixed forests of Kumaun central Himalaya, India. Researcher 5:1-8

Kammesheidt $L$ (1999) Forest recovery by root suckers and above-ground sprouts after slash-and-burn agriculture, fire and logging in Paraguay and Venezuela. J Trop Ecol 15:143-157

Klanderud K, Mbolatiana HZH, Volomboahangy MN, Radimbison MA, Roger E, Totland O, Rajeriarison C (2010) Recovery of plant species richness and composition after slash-and-burn agriculture in a tropical rainforest in Madagascar. Biodivers Conserv 19:187-204

Kotto-Same J, Woomer PL, Appolinaire M, Louis Z (1997) Carbon dynamics in slash-and-burn agriculture and land use alternatives of the humid forest zone in Cameroon. Agric Ecosyst Environ 65:245-256

Liu X, Garcia-Ulloa J, Cornioley T, Liu X, Wang Z, Garci C (2019) Main ecological drivers of woody plant species richness recovery in secondary forests in China. Sci Rep 9:250

Liu X, Liu X, Skidmore A, Garcia C (2017) Recovery of woody plant species richness in secondary forests in China: a meta-analysis. Sci Rep 7:10614

Longworth JB, Williamson GB (2018) Composition and diversity of woody plants in tree plantations versus secondary forests in Costa Rican Lowlands. Trop Conserv Sci 11:1-13

Magurran A (2004) Measuring biological diversity. Blackwell Publishing, Oxford, p 256

Mishra BK, Ramakrishnan PS (1983) Slash and burn agriculture at higher elevations in north-eastern India. II. Soil fertility changes. Agric Ecosyst Environ 9:83-96

Misra R (1968) Ecology work book. Oxford and IBH publishing Co, New Delhi

Mokany K, Raison RJ, Prokushkin AS (2006) Critical analysis of root: shoot ratios in the terrestrial biomes. Global Change Biol 11:1-13

Mukul SA, Herbohn J, Firn J (2016) Tropical secondary forests regenerating after shifting cultivation in the Philippines uplands are important carbon sinks. Sci Rep 6:22483 
Myers N (1991) Tropical forests and climate. Kluwer Publishers, London, pp 3-21 Myers N, Mittermeier RA, Mittermeier CG, da Fonseca GAB, Kent J (2000) Biodiversity hotspots for conservation priorities. Nature 403:853-858

N'Dja K, Justin K, Guillaume D (2008) Successional pattern of plant species and community diversity in a semi-deciduous tropical forest under shifting cultivation. J Veg Sci 19:809-820

Nath AJ, Tiwari BK, Sileshi GW, Sahoo UK, Brahma B, Deb S, Devi NB, Das AK, Reang D, Chaturvedi SS, Tripathi OP, Das DJ, Gupta A (2019) Allometric models for estimation of forest biomass in northeast India. Forests 10:103

Parrish JAD, Bazzaz FA (1982) Niche responses of early and late successional tree seedlings on three resource gradients. Bull Torrey Bot Club 109:451-456

Pelletier J, Codjia C, Potvin C (2012) Traditional shifting agriculture: tracking forest carbon stock and biodiversity through time in western Panama. Glob Change Biol 18:3581-3595

Pickett STA, Kolasa J, Armesto JJ, Collins SL (1989) The ecological concept of disturbance and its expression at various hierarchical levels. Oikos 54:129-136

Ramakrishnan PS (1992) Shifting cultivation and sustainable development: an interdisciplinary study from North-eastern India, UNESC-MAP Series, Paris (republished by Oxford University Press, New Delhi, India)

Rao KS, Ramakrishnan PS (1989) Role of bamboos in nutrient conservation during secondary succession following slash and burn agriculture (Jhum) in northeast India. J Appl Ecol 26:625-633

Read L, Lawrence D (2003) Recovery of biomass following shifting cultivation in dry tropical forests of the Yucatan. Ecol Appl 13:85-97

Rozendaal DAMA, Bongers F, Alde M, Alvarez-Davila E, Ascarrunz N, Balvanera P, Beckvell JM, Bentos T et al (2019) Biodiversity recovery of Neotropical secondary forests. Sci Adv 5:eaau3411

Salinas-Melgoza MA, Skutsch M, Lovett JC (2017) Carbon emissions from dryland shifting cultivation: a case study of Mexican tropical dry forest. Silva Fennica 51:1553

Saxena KG, Ramakrishnan PS (1984) Herbaceous vegetation development and weed potential in slash and burn agriculture (Jhum) in N.E. India. Weed Res 24:135-142

Singnar P, Das MC, Sileshi GW, Brahma B, Nath AJ, Das AK (2017) Allometric scaling, biomass accumulation and carbon stock in different aged stands of thin-walled bamboos Schizostachym dullooa, Pseudostachyum polymorhum and Melocanna baccifera. For Ecol Manage 395:81-91

Thong P, Pebam R, Sahoo UK (2016) Recovery pattern of vegetation during succession following slash and burn agriculture in Mizoram, North-East India. J Plant Biol Soil Health 3:1-8

Thong P, Pebam R, Sahoo UK (2018) A geospatial approach to understand the dynamics of shifting cultivation in Champhai district of Mizoram, North-East India. J Indian Soc Remote 46:1713-1723

Thong P, Sahoo UK, Pebam R, Thangjam U (2019) Spatial and temporal dynamics of shifting cultivation in Manipur, North-East India based on time-series satellite data. Remote Sens App Soc Environ 14:126-137

Tilman D (1982) Resource competition and community structure. Princeton University Press, Princeton

Tilman D, Pacala S (1993) The maintenance of species richness in plant communities. In: Ricklefs RE, Schluter D (eds) Species diversity in Ecological Communities. University of Chicago Press, Chicago, pp 13-25

Toky OP, Ramakrishnan PS (1983) Secondary succession following slash and burn agriculture in north-eastern India. I. Biomass, litter fall and productivity. J Ecol 71:735-745

Ulh C (1987) Factors controlling succession following slash-and-burn agriculture in Amazonia. J Ecol 75:377-407

Vieira ICG, Proctor J (2007) Mechanism of plant regeneration during succession after shifting cultivation in eastern Amazonia. Plant Ecol 192:1573-5052

Walkley A, Black IA (1934) An examination of the Degtjareff method for determining soil organic matter, and a proposed modification of the chromic acid titration method. Soil Sci 37:29-38

Williams MS, Schreuder HT (2000) Guidelines for choosing volume equations in the presence of measurement error in height. Can J For Res 30:306-310

Yamamoto SI (2000) Forest gap dynamics and tree regeneration. J For Res 5: 223-229

Yang B, Zhang W, Lu Y, Zhang W, Wang Y (2019) Carbon storage dynamics of secondary forest succession in the Central Loess Plateau of China. Forests 10(4):342

Yirdaw E, Mong AM, Austin D, Toure I (2019) Recovery of floristic diversity, composition and structure of regrowth forests on fallow lands: implications for conservation and restoration of degraded forest lands in Laos. New Forests 50(6):1007-1027
Zhang Y, Gu F, Liu S, Liu Y, Li C (2013) Variations of carbon stock with forest types in subalpine region of southwestern China. For Ecol Manage 300:88-95

\section{Publisher's Note}

Springer Nature remains neutral with regard to jurisdictional claims in published maps and institutional affiliations.

\section{Submit your manuscript to a SpringerOpen ${ }^{\circ}$ journal and benefit from:}

- Convenient online submission

- Rigorous peer review

- Open access: articles freely available online

High visibility within the field

- Retaining the copyright to your article

Submit your next manuscript at $\boldsymbol{\nabla}$ springeropen.com 